\title{
Synthetic biology for $\mathrm{CO}_{2}$ fixation
}

\author{
Fuyu Gong ${ }^{1,2}$, Zhen $\mathrm{Cai}^{{ }^{1 *}} \&$ Yin $\mathrm{Li}^{1 * *}$ \\ ${ }^{1}$ CAS Key Laboratory of Microbial Physiological and Metabolic Engineering, Institute of Microbiology, Chinese Academy of Sciences, \\ Beijing 100101, China; \\ ${ }^{2}$ University of the Chinese Academy of Sciences, Beijing 100049, China
}

Received September 6, 2016; accepted October 10,2016; published online October 26, 2016

\begin{abstract}
Recycling of carbon dioxide $\left(\mathrm{CO}_{2}\right)$ into fuels and chemicals is a potential approach to reduce $\mathrm{CO}_{2}$ emission and fossil-fuel consumption. Autotrophic microbes can utilize energy from light, hydrogen, or sulfur to assimilate atmospheric $\mathrm{CO}_{2}$ into organic compounds at ambient temperature and pressure. This provides a feasible way for biological production of fuels and chemicals from $\mathrm{CO}_{2}$ under normal conditions. Recently great progress has been made in this research area, and dozens of $\mathrm{CO}_{2}$-derived fuels and chemicals have been reported to be synthesized by autotrophic microbes. This is accompanied by investigations into natural $\mathrm{CO}_{2}$-fixation pathways and the rapid development of new technologies in synthetic biology. This review first summarizes the six natural $\mathrm{CO}_{2}$-fixation pathways reported to date, followed by an overview of recent progress in the design and engineering of $\mathrm{CO}_{2}$-fixation pathways as well as energy supply patterns using the concept and tools of synthetic biology. Finally, we will discuss future prospects in biological fixation of $\mathrm{CO}_{2}$.
\end{abstract}

carbon dioxide fixation, synthetic biology, $\mathrm{CO}_{2}$-fixation pathway, energy supply

Citation: Gong, F., Cai, Z., and Li, Y. (2016). Synthetic biology for $\mathrm{CO}_{2}$ fixation. Sci China Life Sci 59, 1106-1114. doi: 10.1007/s11427-016-0304-2

\section{INTRODUCTION}

Energy and the environment are two major issues that are closely related to human life. World energy consumption in 2011 reached $1.54 \times 1,011 \mathrm{~kW}$ h, a $30 \%$ increase compared with an energy expenditure of $1.18 \times 1,011 \mathrm{~kW} \mathrm{~h}$ in 2000 (Statistical review of world energy, 2013). Fossil fuels (coal, oil, and natural gas) contribute to over $75 \%$ of the world's energy consumption (International Energy Agency, 2014). The burning of fossil fuels has resulted in the massive release of carbon dioxide into the earth's atmosphere, which has generated worldwide concern regarding the associated greenhouse effect. It has been reported that worldwide $\mathrm{CO}_{2}$ emission is increasing each year and reached $3.45 \times 1,010 \mathrm{t}$ in

*Corresponding author (email: caiz@im.ac.cn)

**Corresponding author (email: yli@im.ac.cn)
2012 (Olivier et al., 2013). Therefore, the recycling of $\mathrm{CO}_{2}$ wastes directly into fuels or chemicals is a potential approach to reduce carbon emission and to resolve the potential energy crisis.

Carbon atoms in $\mathrm{CO}_{2}$ molecules are in their highest oxidation state, whereas those in common fuels and chemicals such as hydrocarbons, alcohols, and acids are in lower states. Energy input is thus required to synthesize fuels and chemicals from $\mathrm{CO}_{2}$, which is one of the reasons why $\mathrm{CO}_{2}$ is not extensively used in current chemical industries. However, autotrophic microbes can utilize light to fix atmospheric $\mathrm{CO}_{2}$ through the well-known process of photosynthesis. Recently, much effort has been spent to take advantage of the abilities of autotrophic cyanobacteria and algae through metabolic engineering. The past five years have witnessed great success in this area. To date, dozens of fuels and chemicals including ethanol, butanol, lactic acid, acetone, isobutyraldehyde, 
isoprene, and oil can be synthesized from $\mathrm{CO}_{2}$ by using engineered autotrophic microbes (Angermayr et al., 2012; Atsumi et al., 2009; Bentley and Melis, 2012; Dexter and Fu, 2009; Zhou, 2014; Lan and Liao, 2011; Lan and Liao, 2012; Zhou et al., 2012). Among them, $\mathrm{CO}_{2}$-derived ethanol and lactic acid were produced at a level of grams per liter, demonstrating the potential of $\mathrm{CO}_{2}$ for production of fuels and chemicals.

A deep understanding of natural $\mathrm{CO}_{2}$-fixation pathways and rapid development of synthetic biology have provided us with new insights into this area of research. Great progress in new $\mathrm{CO}_{2}$-fixation pathways and new energy supply patterns continue to emerge in recent years. To comprehensively introduce these new technological advances, we will first briefly introduce the six natural $\mathrm{CO}_{2}$-fixation pathways. This will serve as a gateway to recent progresses in new $\mathrm{CO}_{2}$-fixation pathways and energy supply patterns using synthetic biology (Chao et al., 2015). According to the Royal Academy of Engineering of UK, synthetic biology is defined as the design and engineering of biologically based parts, novel devices, and systems and the redesign of existing natural biological systems (The royal academy of engineering, 2009). Therefore, both design and engineering of synthetic $\mathrm{CO}_{2}$-fixation pathways are included in this review.

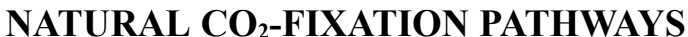

Six natural $\mathrm{CO}_{2}$-fixation pathways have been reported to date (Figure 1), including the Calvin-Benson-Bassham cycle (hereafter, the Calvin cycle), the 3-hydroxypropionate cycle, the Wood-Ljungdahl pathway, the reductive tricarboxylic acid (TCA) cycle, the dicarboxylate/4-hydroxybutyrate cycle, and the 3-hydroxypropionate-4-hydroxybutyrate cycle. The Calvin cycle, the 3-hydroxypropionate cycle, and 3-hydroxypropionate-4-hydroxybutyrate cycle are aerobic, while the others pathways are anaerobic pathways because of the presence of certain oxygen-sensitive enzymes (Ducat and Silver, 2012).

\section{Aerobic $\mathrm{CO}_{2}$-fixation pathways}

The Calvin cycle (Figure 1A), as the most important $\mathrm{CO}_{2}$-fixation pathway in nature from which all crop biomasses obtain their carbon, has attracted great attention from researchers (Stitt et al., 2010). It exists widely in plants, algae, cyanobacteria, and other organisms and is driven by light. This cycle was named after Melvin Ellis Calvin, who discovered it in the 1940s and won the Nobel Prize in Chemistry in 1961. One Calvin cycle converts three molecules of $\mathrm{CO}_{2}$ to one molecule of glyceraldehyde 3-phosphate, with the consumption of nine ATP molecules and six nicotinamide adenine dinucleotide phosphate $(\mathrm{NAD}(\mathrm{P}) \mathrm{H})$ molecules. It is the highest energy-consuming pathway among all six natural $\mathrm{CO}_{2}$-fixation pathways. The $\mathrm{CO}_{2}$-fixing enzyme, $\mathrm{RuBisCO}$, is the rate-limiting enzyme in this cycle, with an average activity of $3.5 \mu \mathrm{mol} \mathrm{min}{ }^{-1} \mathrm{mg}^{-1}$ (Bar-Even et al., 2010). Moreover, $\mathrm{O}_{2}$ in the air is a substrate of RuBisCO and competes with $\mathrm{CO}_{2}$ for activity sites on the enzyme. Reaction with $\mathrm{O}_{2}$ generates phosphoric glyoxylate, which releases $\mathrm{CO}_{2}$ through subsequent photorespiration pathways.

The 3-hydroxypropionate cycle (Figure 1B) exists in photosynthetic green nonsulfur bacteria and is driven by light (Herter et al., 2001; Strauss and Fuchs, 1993). This cycle is the most complex, containing 16 enzymatic reaction steps that are catalyzed by 13 enzymes. In contrast to the Calvin cycle, which converts $\mathrm{CO}_{2}$ to glyceraldehyde 3-phosphate, this cycle converts three molecules of $\mathrm{HCO}_{3}{ }^{-}$into one molecule of pyruvate, with the addition of five ATP and NAD(P)H molecules. There are two $\mathrm{CO}_{2}$-fixing enzymes in this cycle: acetyl-CoA carboxylase and propionyl-CoA carboxylase.

Another archaeal aerobic $\mathrm{CO}_{2}$-fixation pathway discovered in 2007 is the 3-hydroxypropionate-4-hydroxybutyrate cycle, which is driven by sulfur and hydrogen (Figure 1F) (Berg et al., 2007). This cycle synthesizes one molecule of acetyl coenzyme A from two molecules of $\mathrm{HCO}_{3}{ }^{-}$, four molecules of ATP, and four equal molecules of $\mathrm{NAD}(\mathrm{P}) \mathrm{H}$. The two $\mathrm{CO}_{2}-$ fixing enzymes used are the same as those of the 3-hydroxypropionate cycle.

\section{Anaerobic $\mathrm{CO}_{2}$-fixation pathways}

The Wood-Ljungdahl pathway (Figure 1C), which exists mainly in acetate-producing anaerobes, was identified in the 1970s by Harland G. Wood and Lars G. Ljungdahl (Ragsdale, 1997) and uses hydrogen as its energy source. It is the only non-cycle $\mathrm{CO}_{2}$-fixation pathway, contains the fewest reaction steps, and consumes the least amount of energy. This pathway converts two molecules of $\mathrm{CO}_{2}$ (or one molecule of $\mathrm{CO}_{2}$ and one molecule of carbon monoxide) into one molecule of acetyl coenzyme A, using one ATP and four $\mathrm{NAD}(\mathrm{P}) \mathrm{H}$ molecules. It is therefore called the anaerobic acetyl coenzyme A pathway (Drake, 1994).

The reductive TCA cycle (Figure 1D) exists in photosynthetic green sulfur bacteria and anaerobic bacteria. This cycle generates one molecule of acetyl coenzyme A via two molecules of $\mathrm{CO}_{2}$, with the consumption of two ATP and four NAD(P)H molecules (Evans et al., 1966; Kim et al., 1992). The two $\mathrm{CO}_{2}$-fixing enzymes in this cycle are $\alpha$-ketoglutarate synthase and isocitrate dehydrogenase. The enzyme $\alpha$-ketoglutarate synthase is strictly anaerobic, with unknown activity. Isocitrate dehydrogenase has the highest activity amongst all $\mathrm{CO}_{2}$-fixing enzymes listed in Table 1 (Berg, 2011).

The archaeal anaerobic $\mathrm{CO}_{2}$-fixation pathway-the dicarboxylate/4-hydroxybutyrate cycle (Figure 1E) — was discovered in 2008. This cycle uses sulfur and hydrogen as energy sources (Huber et al., 2008). One molecule each of $\mathrm{CO}_{2}$ and 

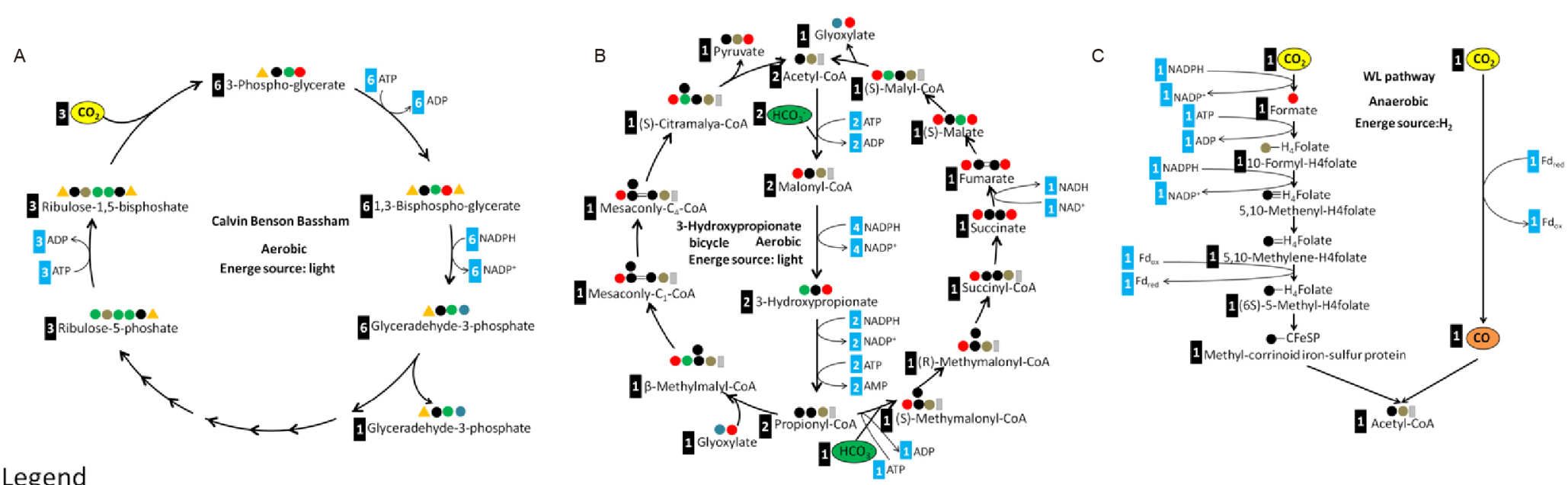

Legend

$\bullet$ Hydrocarbon Carboxy @ Carbonxy $\bullet$ Aldehyde

-Hydroxyl $\triangle$ Phosphate $\llbracket \mathrm{COA} \quad=$ Double bond $\equiv$ Triple bond

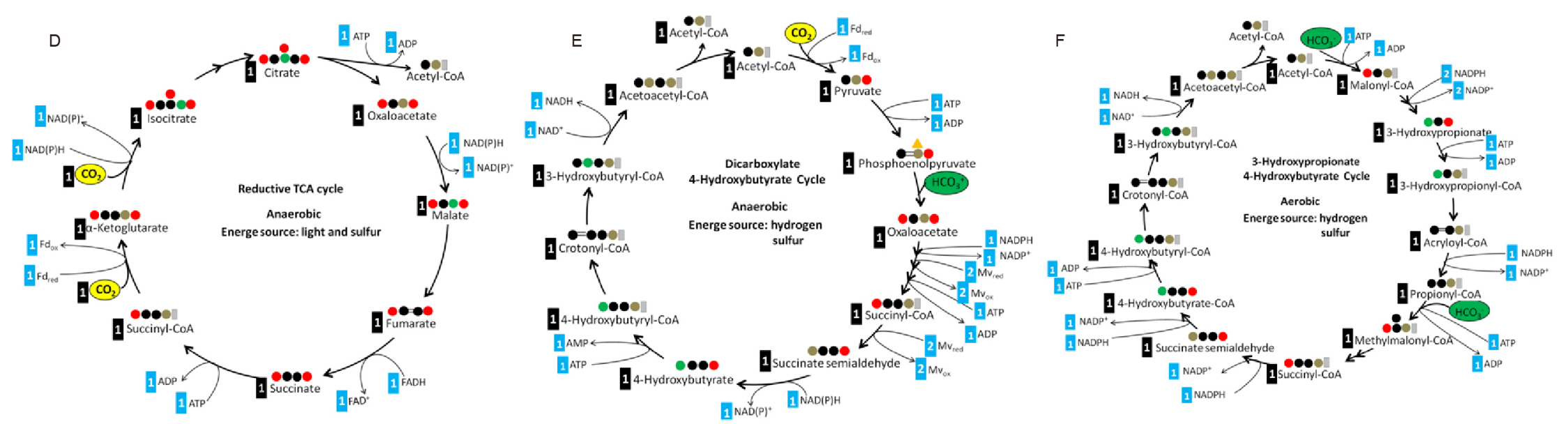

Figure 1 Six natural $\mathrm{CO}_{2}$-fixation pathways. A, Calvin cycle; B, 3-hydroxypropionate cycle; C, Wood-Ljungdahl pathway; D, reductive TCA cycle; E, dicarboxylate/4-hydroxybutyrate cycle; F, 3-hydroxypropionate/4-hydroxybutyrate cycle. 
Table 1 Summary of the six natural $\mathrm{CO}_{2}$-fixation pathwaysa)

\begin{tabular}{|c|c|c|c|c|c|c|c|c|c|c|}
\hline & Organisms & Energy & Species & $\begin{array}{l}\text { Reaction } \\
\text { numbers }\end{array}$ & Total reaction equations & $\begin{array}{l}\mathrm{ATP} / \mathrm{CO}_{2} \\
(\mathrm{~mol} / \mathrm{mol})\end{array}$ & $\begin{array}{c}\mathrm{NAD}(\mathrm{P}) \mathrm{Ha} \\
/ \mathrm{CO}_{2} \\
(\mathrm{~mol} / \mathrm{mol})\end{array}$ & $\begin{array}{c}\mathrm{CO}_{2} \text {-fixing } \\
\text { enzymes }\end{array}$ & 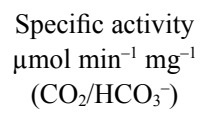 & Reference \\
\hline A & $\begin{array}{l}\text { Plant } \\
\text { Algae } \\
\text { Cyanobac- } \\
\text { teria }\end{array}$ & Light & $\begin{array}{c}\text { Maize } \\
\text { Scenedesmus sp. } \\
\text { Synechocystis sp. }\end{array}$ & 13 & $\begin{array}{c}3 \mathrm{CO}_{2}+9 \mathrm{ATP}+ \\
6 \mathrm{NAD}(\mathrm{P}) \mathrm{H} \rightarrow \mathrm{GA}-3 \mathrm{P}+ \\
9 \mathrm{ADP}+6 \mathrm{NAD}(\mathrm{P})^{+}+8 \mathrm{Pi}\end{array}$ & 3 & 2 & $\begin{array}{c}\text { RuBisCO (EC: } \\
\text { 2.1.1.127) }\end{array}$ & 3.5 & $\begin{array}{l}\text { (Bar-Even et al., } \\
\text { 2010; Calvin, } \\
\text { 1949; Calvin and } \\
\text { Massini, 1952) }\end{array}$ \\
\hline B & $\begin{array}{c}\text { Green } \\
\text { nonsulfur } \\
\text { bacteria }\end{array}$ & Light & $\begin{array}{l}\text { Chloroflexus } \\
\text { aurantiacus }\end{array}$ & 16 & $\begin{array}{c}3 \mathrm{HCO}_{3}{ }^{-}+5 \mathrm{ATP}^{+} \\
5 \mathrm{NAD}(\mathrm{P}) \mathrm{H} \rightarrow \text { Pyruvate }+ \\
3 \mathrm{ADP}+2 \mathrm{AMP}+3 \mathrm{Pi}+ \\
2 \mathrm{PPi}+5 \mathrm{NAD}(\mathrm{P})^{+}\end{array}$ & 1.67 & 1.67 & $\begin{array}{l}\quad \text { Acetyl-CoA } \\
\text { carboxylase (EC: } \\
\quad 6.4 .1 .2) \\
\text { Propionyl-CoA } \\
\text { carboxylase (EC: } \\
6.4 .1 .3)\end{array}$ & $\begin{array}{l}18 \\
30\end{array}$ & $\begin{array}{l}\text { (Bar-Even et al., } \\
\text { 2010; Herter } \\
\text { et al., 2001; } \\
\text { STRAUSS and } \\
\text { FUCHS, 1993) }\end{array}$ \\
\hline $\mathrm{C}$ & $\begin{array}{l}\text { Anaerobic } \\
\text { bacteria }\end{array}$ & $\begin{array}{l}\text { Hydro- } \\
\text { gen }\end{array}$ & $\begin{array}{l}\text { Clostridium } \\
\text { ljungdahlii }\end{array}$ & 8 & $\begin{array}{c}2 \mathrm{CO}_{2}+\mathrm{ATP}+2 \mathrm{NAD}(\mathrm{P}) \mathrm{H}+ \\
2 \mathrm{Fd}_{\mathrm{red}}+\mathrm{CoASH} \rightarrow \mathrm{AcCoA}+ \\
\mathrm{ADP}+\mathrm{Pi}+2 \mathrm{NADP}^{+}+2 \mathrm{Fd}_{\mathrm{ox}}\end{array}$ & 0.5 & 2 & $\begin{array}{l}\text { Formate } \\
\text { dehydrogenase } \\
\text { (EC: } 1.2 .1 .2 \text { ) } \\
\text { CO dehydro- } \\
\text { genate/Acetyl- } \\
\text { CoA synthase } \\
\text { (EC: } 2.3 .1 .169)\end{array}$ & 2.34 & $\begin{array}{c}\text { (Drake, 1994; } \\
\text { Ragsdale, 1997) }\end{array}$ \\
\hline $\mathrm{D}$ & $\begin{array}{c}\text { Green sulfur } \\
\text { bacteria }\end{array}$ & $\begin{array}{l}\text { Light } \\
\text { Sulfur }\end{array}$ & $\begin{array}{c}\text { Chlorobiumthio- } \\
\text { sulfatophilum }\end{array}$ & 9 & $\begin{array}{c}2 \mathrm{CO}_{2}+2 \mathrm{ATP}+2 \mathrm{NAD}(\mathrm{P}) \mathrm{H}+ \\
\mathrm{FADH}+\mathrm{Fd}_{\mathrm{red}}+\mathrm{CoASH} \rightarrow \\
\mathrm{AcCoA}+2 \mathrm{ADP}+2 \mathrm{Pi}+ \\
2 \mathrm{NAD}(\mathrm{P})^{+}+\mathrm{FAD}^{+}+\mathrm{Fd}_{\mathrm{ox}}\end{array}$ & 1 & 2 & $\begin{array}{l}\text { 2-Oxoglutarate } \\
\text { synthase (EC: } \\
\quad 1.2 .7 .3) \\
\text { Isocitrate } \\
\text { dehydrogenase } \\
\text { (EC: } 1.1 .1 .87 \text { ) }\end{array}$ & $\begin{array}{l}- \\
53\end{array}$ & $\begin{array}{l}\text { (Bar-Even et al., } \\
\text { 2010; Evans et } \\
\text { al., 1966; Kim } \\
\text { et al., 1992) }\end{array}$ \\
\hline E & Archaea & $\begin{array}{l}\text { Hydro- } \\
\text { gen }\end{array}$ & $\begin{array}{l}\text { Ignicoccus } \\
\text { hospitalis }\end{array}$ & 14 & $\begin{array}{c}\mathrm{CO}_{2}+\mathrm{HCO}_{3}^{-}+3 \mathrm{ATP}+ \\
\mathrm{NAD}(\mathrm{P}) \mathrm{H}+\mathrm{Fd}_{\mathrm{red}}+4 \mathrm{MV}_{\text {red }}+ \\
\mathrm{CoASH} \rightarrow \mathrm{AcCoA}+2 \mathrm{ADP}+ \\
\mathrm{AMP}+2 \mathrm{Pi}+2 \mathrm{PPi}+\mathrm{NAD}(\mathrm{P})^{+} \\
+\mathrm{Fd}_{\mathrm{ox}}+4 \mathrm{MV}_{\mathrm{ox}}\end{array}$ & 1.5 & 2 & 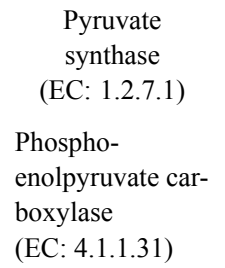 & - & $\begin{array}{c}\text { (Bar-Even et al., } \\
\text { 2010; Huber et } \\
\text { al., 2008) }\end{array}$ \\
\hline $\mathrm{F}$ & Archaea & $\begin{array}{l}\text { Hydro- } \\
\text { gen } \\
\text { Sulfur }\end{array}$ & $\begin{array}{l}\text { Metallosphaera } \\
\text { sedula }\end{array}$ & 16 & $\begin{array}{c}2 \mathrm{HCO}_{3}{ }^{-}+4 \mathrm{ATP}+ \\
4 \mathrm{NAD}(\mathrm{P}) \mathrm{H}+\mathrm{CoASH} \rightarrow \\
\mathrm{AcCoA}+3 \mathrm{ADP}+3 \mathrm{Pi}+ \\
\mathrm{AMP}+\mathrm{PPi}+4 \mathrm{NADP}^{+}\end{array}$ & 2 & 2 & $\begin{array}{l}\quad \text { Acetyl-CoA } \\
\text { carboxylase (EC: } \\
\quad 6.4 .1 .2) \\
\text { Propionyl-CoA } \\
\text { carboxylase (EC: } \\
\text { 6.4.1.3) }\end{array}$ & $\begin{array}{l}18 \\
30\end{array}$ & $\begin{array}{c}\text { (Bar-Even et al., } \\
\text { 2010; Berg et } \\
\text { al., 2007) }\end{array}$ \\
\hline
\end{tabular}

a) $1 \mathrm{Fd}_{\mathrm{red}}=1 \mathrm{NAD}(\mathrm{P}) \mathrm{H} ; 1 \mathrm{FADH}=1 \mathrm{NAD}(\mathrm{P}) \mathrm{H} ; 2 \mathrm{MV}_{\mathrm{re}}=1 \mathrm{NAD}(\mathrm{P}) \mathrm{H}$ 
$\mathrm{HCO}_{3}{ }^{-}$are used to synthesize one molecule of acetyl coenzyme A, consuming three ATP and four NAD $(\mathrm{P}) \mathrm{H}$ molecules. The $\mathrm{CO}_{2}$-fixing enzymes in this cycle are pyruvate synthase and phosphoenolpyruvate carboxylase. Pyruvate synthase is another strictly anaerobic enzyme with unknown activity. It is reported that the $\mathrm{KM}$ of phosphoenolpyruvate carboxylase to $\mathrm{HCO}_{3}{ }^{-}$is the smallest amongst all carboxylases listed in Table 1 (Oleary, 1982), demonstrating its high affinity for $\mathrm{HCO}_{3}{ }^{-}$. Notably, the doubling time of autotrophic archaea Ignicoccus hospitalis, which utilizes this $\mathrm{CO}_{2}$-fixation pathway, is only 1 $\mathrm{h}$ under optimal growth conditions (Jahn et al., 2007). This may be partly contributed by the strong affinity of phosphoenolpyruvate carboxylase.

\section{DESIGNING AND ENGINEERING $\mathrm{CO}_{2}$-FIXATION PATHWAYS BY SYNTHETIC BIOLOGY}

Research progress in this area is summarized in Table 2, which can be divided into three parts: (i) computer-aided design of new $\mathrm{CO}_{2}$-fixation pathways and relocation of natural $\mathrm{CO}_{2}$-fixation pathways; (ii) engineering $\mathrm{CO}_{2}$-fixation pathways by increasing the $\mathrm{CO}_{2}$ supply; and (iii) engineering $\mathrm{CO}_{2}$-fixation pathways by enhancing activities of $\mathrm{CO}_{2}$-fixing enzymes.

\section{Design and relocation of $\mathrm{CO}_{2}$-fixation pathway}

Designing an efficient $\mathrm{CO}_{2}$-fixation pathway is the ultimate aim of synthetic biology, but is still faced with great challenges at the current stage. There is only one reported work on this technology: in 2010, Bar-Even et al. computationally obtained a series of synthetic $\mathrm{CO}_{2}$-fixation pathways that combined existing metabolic building blocks from various organisms, based on the properties of approximately 5,000 natural enzymes (Bar-Even et al., 2010). The kinetics, energetics, and topologies of both synthetic and natural pathways were compared. One synthetic pathway, which employed the most effective $\mathrm{CO}_{2}$-fixing enzyme, phosphoenolpyruvate carboxylase, was based on the $\mathrm{C} 4$ cycle and was predicted to be two to three times faster than the Calvin cycle. However, construction of such a cycle was still restricted by uncertainties in the expression, activity, stability, and regulation of all enzymes in this pathway.

Recently, relocation of natural $\mathrm{CO}_{2}$-fixation pathways has

Table 2 Recent progress in designing and engineering $\mathrm{CO}_{2}$-fixation pathways by synthetic biology

\begin{tabular}{|c|c|c|c|}
\hline & Results & Year & Reference \\
\hline \multirow{6}{*}{$\begin{array}{l}\text { Design and relocation of } \\
\mathrm{CO}_{2} \text {-fixation pathway }\end{array}$} & Designed alternative synthetic $\mathrm{CO}_{2}$-fixation pathways by computer & 2010 & $\begin{array}{l}\text { (Bar-Even et al., } \\
\text { 2010) }\end{array}$ \\
\hline & $\begin{array}{l}\text { Divided the 3-hydroxypropionate cycle from Chloroflexus aurantiacus into } \\
\text { four sub-pathways and expressed them separately in Escherichia coli }\end{array}$ & 2013 & (Mattozzi et al., 2013) \\
\hline & $\begin{array}{c}\text { Produced 3-hydroxypropionate from } \mathrm{CO}_{2} \text { by Pyrococcus furiosus } \\
\text { introduced with partial 3-hydroxypropionate/4-hydroxybutyrate } \\
\text { cycle from Metallosphaera sedula }\end{array}$ & 2013 & (Keller et al., 2013) \\
\hline & $\begin{array}{c}\text { Recycled } \mathrm{CO}_{2} \text { in an engineered } E \text {. coli with introduction of } \\
\text { partial cyanobacterial Calvin cycle }\end{array}$ & 2013 & $\begin{array}{l}\text { (Zhuang and Li, } \\
\text { 2013) }\end{array}$ \\
\hline & $\begin{array}{l}\text { Developed a relative quantification approach to calculate the } \mathrm{CO}_{2} \text {-fixation } \\
\text { efficiency in E. coli with partial cyanobacterial Calvin cycle }\end{array}$ & - & (Gong et al., 2015) \\
\hline & $\begin{array}{l}\text { Increased ethanol yield in Saccharomyces cerevisiae with par- } \\
\text { tial cyanobacterial Calvin cycle }\end{array}$ & 2013 & $\begin{array}{l}\text { (Guadalupe-Medina } \\
\text { et al., 2013) }\end{array}$ \\
\hline \multirow{3}{*}{$\begin{array}{l}\text { Engineering the } \mathrm{CO}_{2} \text {-fixation } \\
\text { pathway by increasing the } \\
\qquad \mathrm{CO}_{2} \text { supply }\end{array}$} & Reconstructed cyanobacterial carboxysome in $E$. coli & 2012 & (Bonacci et al., 2012) \\
\hline & $\begin{array}{l}\text { Improved } \mathrm{CO}_{2} \text {-fixation efficiency of an } \mathrm{CO}_{2} \text {-fixing } E \text {. coli by } \\
\text { introduction of carbonic anhydride }\end{array}$ & - & (Gong et al., 2015) \\
\hline & $\begin{array}{l}\text { Introduced a bypass photorespiration pathway into the } E \text {. coli glycolate } \\
\text { metabolic pathway to release } \mathrm{CO}_{2} \text { into the chloroplast }\end{array}$ & 2007 & (Kebeish et al., 2007) \\
\hline \multirow{5}{*}{$\begin{array}{l}\text { Engineering the } \mathrm{CO}_{2} \text {-fixation } \\
\text { pathway by improving the } \\
\qquad \mathrm{CO}_{2} \text {-fixing enzyme }\end{array}$} & $\begin{array}{l}\text { Developed an activity-directed selection method for RuBisCO } \\
\text { and increased the specific carboxylation activity of RuBisCO in } \\
\text { Synechococcus sp. PCC } 7002 \text { by } 85 \%\end{array}$ & 2014 & (Cai et al., 2014) \\
\hline & $\begin{array}{l}\text { Increased thermotolerance of } \mathrm{RuBisCO} \text { activase from Arabidopsis } \\
\text { thaliana to improve the stability of } \mathrm{RuBisCO}\end{array}$ & 2009 & (Kumar et al., 2009) \\
\hline & $\begin{array}{l}\text { Replaced the tobacco RuBisCO with cyanobacteria } \mathrm{RuBisCO} \text { and observed } \\
\text { significantly increased growth rate of tobacco under high concentration of } \mathrm{CO}_{2}\end{array}$ & 2014 & (Lin et al., 2014) \\
\hline & $\begin{array}{c}\text { Constructed a hybrid RuBisCO from different RuBisCO large and small } \\
\text { subunits and studied its enzymatic properties }\end{array}$ & - & $\begin{array}{l}\text { (Genkov et al., 2010; } \\
\text { Ishikawa et al., 2011) }\end{array}$ \\
\hline & $\begin{array}{l}\text { Reported that over-expressing the sedoheptulose-1-7 bisphosphatase } \\
\text { improves photosynthetic carbon gain and yield }\end{array}$ & 2011 & $\begin{array}{l}\text { (Rosenthal et al., } \\
\text { 2011) }\end{array}$ \\
\hline
\end{tabular}


received much attention, as engineering natural $\mathrm{CO}_{2}$-fixing autotrophic microbes is usually difficult. In 2013, Mattozzi et al. divided the 16 steps of the 3-hydroxypropionate cycle from Chloroflexus aurantiacus into four sub-pathways and expressed each sub-pathway in Escherichia coli (Mattozzi et al., 2013). Each sub-pathway was found to be functional, which provided a basis for the potential synthesis of $\mathrm{CO}_{2}$-fixing E. coli. In the same year, Keller et al. expressed a part of the 3-hydroxypropionate/4-hydroxybutyrate cycle from the archaea Metallosphaera sedula (optimum growth temperature of $73^{\circ} \mathrm{C}$ ) in another archaea Pyrococcus furiosus (optimum growth temperature of $100^{\circ} \mathrm{C}$ ) (Keller et al., 2013). This engineered strain can synthesize a valuable industrial chemical, 3-hydroxypropionic acid, from $\mathrm{CO}_{2}$, using hydrogen as the energy source.

The above two studies successfully introduced a natural $\mathrm{CO}_{2}$-fixation pathway into another host but failed to direct the carbon flux from the $\mathrm{CO}_{2}$-fixation pathway into the host's central metabolic network. In order to conjugate the introduced $\mathrm{CO}_{2}$-fixation pathway with the central metabolic network so that the fixed carbon can be efficiently utilized by the host for cell growth, two intermediates in the Calvin cycle, ribulose 5-phosphate $(\mathrm{Ru} 5 \mathrm{P})$ and 3-phosphoglycerate (3PGA), were selected as nodes to connect the host's central pentose phosphate pathway with the glycolysis pathway. By constructing a $\mathrm{CO}_{2}$-fixing bypass in the central metabolic pathways, $\mathrm{CO}_{2}$ recycling and increased ethanol yield were observed in E. coli (Zhuang and Li, 2013) and Saccharomyces cerevisiae (Guadalupe-Medina et al., 2013), respectively. However, these studies were unable to determine the amount of $\mathrm{CO}_{2}$ that had been fixed by the central metabolic pathways. Recently, we have developed a relative quantification method to calculate the ratio of carbon flux from the $\mathrm{CO}_{2}$-fixation pathway and the central metabolic pathway by LC/MS/MS detection of ${ }^{13} \mathrm{C}$ and unlabeled metabolites (Gong et al., 2015).

After reconstructing the carbon fixation pathway, researchers must consider methods to further improve the efficiency of carbon fixation. There are two methods for this improvement. The first is to increase the concentration of inorganic carbon substrates. The second is to enhance the metabolic flux. Current research is mainly focused on reconstructing enzymes in the carbon fixation pathways.

\section{Engineering of $\mathrm{CO}_{2}$-fixation pathways via increase in $\mathrm{CO}_{2}$ supply}

Cyanobacteria and $\mathrm{C} 4$ plants employ the carbon-concentrating mechanism (CCM) to increase intracellular inorganic carbon concentrations. CCM is accomplished by the organelle carboxysome in cyanobacteria. Bicarbonate is transported into the carboxysome, converted to $\mathrm{CO}_{2}$ by carbonic anhydrase, and catalyzed by the encapsulated RuBisCO therein. The protein shell of carboxysome is positively charged and thus acts as a barrier to prevent loss of $\mathrm{CO}_{2}$ and facilitates build-up of $\mathrm{CO}_{2}$ around $\mathrm{RuBisCO}$. It has been reported that $\mathrm{CO}_{2}$ concentration in the carboxysome is approximate a 1,000-fold higher than that of the outside (Badger and Price, 2003). In $\mathrm{C} 4$ plants, atmospheric $\mathrm{CO}_{2}$ is first captured by the highly active phosphate pyruvate carboxylase in the mesophyll cells to produce 4-carbon organic acids such as malate and oxaloacetate. These 4-carbon organic acids are transported into the bundle sheath cells to release $\mathrm{CO}_{2}$ by actions of decarboxylases and then converted to energy-rich molecules such as glucose by RuBisCO therein. The $\mathrm{CO}_{2}$ concentration is approximate 10-fold higher in the bundle sheath cells compared to outside the cells, as these cells can prevent the diffusion of $\mathrm{CO}_{2}$.

Much work has been done to simulate CCMs. In 2012, Bonacci et al. introduced shell proteins of cyanobacterial carboxysome into $E$. coli and observed the assembly of icosahedral complexes in E. coli (Bonacci et al., 2012). This was the first evidence to suggest the possibility that reconstruction of the CCM in a heterologous host can induce heterotrophic $\mathrm{CO}_{2}$-fixation. However, the function of this synthetic carboxysome in the heterologous host was not reported. We recently introduced cyanobacterial carbonic anhydrase, a key enzyme in the cyanobacterial CCM, into E. coli. Improved $\mathrm{CO}_{2}$-fixation efficiency was found in the engineered $\mathrm{CO}_{2}$-fixing $E$. coli, demonstrating that the CCM can also be transplanted into heterotrophic microbes (Gong et al., 2015). Ideas on introducing the CCM from cyanobacteria or $\mathrm{C} 4$ plants into $\mathrm{C} 3$ crops to improve the photosynthetic efficiency of the latter (Covshoff and Hibberd, 2012; Price et al., 2011; Price et al., 2013) have been reported, but much research is still needed on the topic.

Designing a new CCM is an alternative strategy to reconstructing CCMs from cyanobacteria. In 2007, Kebeish et al. developed a new approach to increase $\mathrm{CO}_{2}$ concentration in plant chloroplasts (Kebeish et al., 2007). They introduced three genes of the E. coli glycolate catabolic pathway into Arabidopsis thaliana chloroplasts. This new pathway replaced plant photorespiration, which occurred in the peroxisomes and the mitochondria. Therefore, $\mathrm{CO}_{2}$ that should have been released into the cytoplasm through photorespiration was released into the chloroplasts. As a result, $\mathrm{CO}_{2}$ concentrations in chloroplasts were increased for carbon fixation by $\mathrm{RuBisCO}$. This design provided a new alternative photorespiration pathway that can improve photosynthesis and possibly increase crop yield.

\section{Engineering the $\mathrm{CO}_{2}$-fixation pathway by enhancing $\mathrm{CO}_{2-}$ fixing enzymes}

$\mathrm{RuBisCO}$, the rate-limiting $\mathrm{CO}_{2}$-fixing enzyme in the Calvin cycle, has long been the primary engineering target, since $\mathrm{CO}_{2}$-fixation efficiency was believed to be associated with the crop production. $\mathrm{RuBisCO}$ is a bifunctional enzyme with 
both carboxylation activity towards $\mathrm{CO}_{2}$ and oxygenation activity toward $\mathrm{O}_{2}$. Therefore, manipulation of $\mathrm{RuBisCO}$ activity involves enhancement of its extremely slow carboxylation activity and reduction of its oxygenation activity. However, engineering of RuBisCO has made little progress in the past ten years, as it has a complex hexadecamer structure, but lacks sufficient structure-function relationships. Recent engineering by directed evolution was successful in improving its heterologous expression in E. coli, but still failed to improve its carboxylation activity and selectivity (Whitney et al., 2011). This year, we developed an activity-directed selection system for RuBisCO and successfully improved the specific carboxylation activity of RuBisCO from Synechococcus sp. PCC 7002 by $85 \%$ (Cai et al., 2014). Mutant analyses revealed that all mutations occurred in the small subunit, emphasizing the long-term overlooked contribution of the small-subunit to its catalytic activity.

Another engineering target is $\mathrm{RuBisCO}$ activase, which is required by some $\mathrm{RuBisCO}$ for activation prior to every catalytic cycle. Kumar et al. found that improving the thermal stability of RuBisCO activase increased stability of RuBisCO within a certain temperature range (Kumar et al., 2009).

To further enhance the $\mathrm{CO}_{2}$-fixation efficiency of crop plants as a means to increase crop production, chimeric $\mathrm{RuBisCOs}$ from various sources have been reported. Lin et al. knocked-out the large subunit of RuBisCO in tobacco and inserted genes for large and small RuBisCO subunits from Synechococcus elongatus PCC7942. The transgenic tobacco was able to grow at high $\mathrm{CO}_{2}$ concentrations. This work was the first step to implement the carbon concentrationg mechanisms from cyanobacterial to tobacco, with the potential of increasing its photosynthetic efficiency (Lin et al., 2014). Genkov et al. replaced the small subunit of Chlamydomonas $\mathrm{RuBisCO}$ with that of plants (e.g., spinach, Arabidopsis, sunflower). Compared with the Chlamydomonas RuBisCO, the engineered $\mathrm{RuBisCO}$ hybrids demonstrated high selectivity, albeit at a decreased catalytic efficiency (Genkov et al., 2010). Aside from engineering of RuBisCO, increasing Calvin cycle intermediates also improved efficiencies of carbon fixation. For example, Rosenthal et al. over-expressed sedoheptulose-1,7-bisphosphatase in tobacco to increase the reproduction rate of ribulose-1,5-bisphosphate (RuBP). This consequently increased efficiency of $\mathrm{CO}_{2}$ fixation and growth of tobacco (Rosenthal et al., 2011).

\section{DESIGNING ENERGY SUPPLY PATTERNS FOR $\mathrm{CO}_{2}$-FIXATION}

Energy input is required for $\mathrm{CO}_{2}$ fixation. Autotrophic microbes naturally employ light, sulfur, and hydrogen as their energy source, while energy for heterotrophic $\mathrm{CO}_{2}$ fixation comes mainly from metabolism of sugar. Recently, new energy supply patterns have been attempted for $\mathrm{CO}_{2}$ fixation in both autotrophic and heterotrophic microbes, the results of which have paved an exciting starting point in this field.

\section{New energy supply for $\mathrm{CO}_{2}$-fixation in autotrophic mi- crobes}

To date, electricity is the sole new energy that autotrophic microbes can utilize. In 2012, Li et al. reported that an engineered Ralstonia eutropha $\mathrm{H} 16$ could utilize electricity for $\mathrm{CO}_{2}$ fixation to produce higher alcohols such as 3-methyl1-butanol and isobutanol (Li et al., 2012). Another example used the concept of a reverse microbial fuel cell to transform electricity to energy forms that can be used by microbes. Electricity was first used to reduce nitrite to ammonia, the latter of which can be used as an energy source for cell growth and $\mathrm{CO}_{2}$ fixation in the chemoautotroph Nitrosomonas europaea (Khunjar et al., 2012).

\section{New energy supplies for $\mathrm{CO}_{2}$-fixation in heterotrophic mi- crobes}

Engineering of heterotrophs to utilize electricity or light as the sole energy resource has been reported. For electricity utilization, it has been reported that electrical current can be directly applied to a gram-positive bacterium to produce methane from $\mathrm{CO}_{2}$ by electromethanogenesis (Cheng et al., 2009). In 2010, Nevin et al. used a graphite electrode to provide electrons for the acetogenic heterotroph Sporomusa ovata, which was grown in biofilm form on the cathode surface (Nevin et al., 2010). The electrons were then used by the bacterial strain to reduce $\mathrm{CO}_{2}$ to produce acetate and a small amount of 2-oxobutyrate.

There are two strategies in utilization of light. Direct light utilization includes reconstruction of natural photosystems in heterotrophic microbes. Compared with photosystems I and II, the proteorhodopsin photosystem is a relatively simple one. In 2007, Martinez et al. expressed six genes from the proteorhodopsin photosystem of marine picoplankton into $E$. coli and successfully enabled photophosphorylation in $E$. coli exposed to light (Martinez et al., 2007). Indirect utilization of light first converts light to electricity in vitro and then provides electricity for microbes to convert $\mathrm{CO}_{2}$ into organic compounds (Yu, 2012). This strategy was inspired by the development of photovoltaic technology and by the fact that some microbes are already capable of utilizing electricity. Other energy resources (e.g., heat, mechanical, and nuclear energy), currently unavailable for microbes, can also be transformed into electricity in vitro to be used by microbes.

\section{CONCLUDING REMARKS}

Conversion of $\mathrm{CO}_{2}$ to fuels and chemicals is an area of great interest, as it provides potential solutions to both environmental and energy issues. Homogeneous and heterogeneous catalytic hydrogenation and photocatalysis are capable of con- 
verting $\mathrm{CO}_{2}$ into energy through chemical reactions. However, $\mathrm{CO}_{2}$ is not used extensively as a raw material in the current industry, possibly because large amount of input energy is required to reduce the $\mathrm{CO}_{2}$ molecules. Billions of years of natural evolution have created a biological route for $\mathrm{CO}_{2}$ fixation. Although great success has been made in microbial production of fuels and chemicals from $\mathrm{CO}_{2}$ during the past five years, achieving this on an industrial scale is still not feasible. Inefficiencies in $\mathrm{CO}_{2}$ fixation mainly lie in inefficient natural pathways and the energy supply.

Six natural carbon-fixation pathways have been reported to date. Because the Calvin cycle is the primary pathway in plants, algae, and cyanobacteria and the pathway enzymes can be easily expressed heterologously, most engineering efforts have been directed towards the Calvin cycle. However, the past ten years of research have made little progress. Aside from difficulties in engineering $\mathrm{RuBisCO}$, the energy requirements of the Calvin cycle are the highest amongst the six pathways. Therefore, this pathway may not be the best choice for $\mathrm{CO}_{2}$ fixation. We believe that with new developments in synthetic biology, such as the computer-aided design of new synthetic $\mathrm{CO}_{2}$-fixation pathways, there will be an increase in manipulation of other $\mathrm{CO}_{2}$-fixation pathways.

Concerning the energy supply issue, solar energy is the cheapest resource. However, the reconstruction of complex biological photosynthesis systems is very difficult. Based on preliminary results on usage of electric energy by microbes and the development of photovoltaic technology, multiple energy resources may be used for $\mathrm{CO}_{2}$ fixation.

We have already seen that with the powerful concepts and tools of synthetic biology, researchers are able to design and engineer new $\mathrm{CO}_{2}$-fixing elements, pathways, and energy supply systems. We believe that further progress will continue to be made in this field of research. In the near future, synthetic modules or microbes may be used in the industry to produce fuels and chemicals from $\mathrm{CO}_{2}$.

Compliance and ethics The author(s) declare that they have no conflict of interest.

Acknowledgements This work was supported by the National Basic Research Program of China (31470231), and National Natural Science Foundation of China (21106175).

2014 Key world energy statistics. (2014). International Energy Agency pp. 24-28.

Statistical review of world energy. (2013). workbook (xlsx). (London: BP). Angermayr, S.A., Paszota, M., and Hellingwerf, K.J. (2012). Engineering a cyanobacterial cell factory for production of lactic acid. Appl Environ Microbiol 78, 7098-7106.

Atsumi, S., Higashide, W., and Liao, J.C. (2009). Direct photosynthetic recycling of carbon dioxide to isobutyraldehyde. Nat Biotechnol 27, 1177-1180.

Badger, M.R., and Price, G.D. (2003). $\mathrm{CO}_{2}$ concentrating mechanisms in cyanobacteria: molecular components, their diversity and evolution. J Exp Bot 54, 609-622.

Bar-Even, A., Noor, E., Lewis, N.E., and Milo, R. (2010). Design and analysis of synthetic carbon fixation pathways. Proc Natl Acad Sci USA 107, 8889-8894.

Bentley, F.K., and Melis, A. (2012). Diffusion-based process for carbon dioxide uptake and isoprene emission in gaseous/aqueous two-phase photobioreactors by photosynthetic microorganisms. Biotechnol Bioeng $109,100-109$.

Berg, I.A. (2011). Ecological aspects of the distribution of different autotrophic $\mathrm{CO}_{2}$ fixation pathways. Appl Environ Microbiol 77, 1925-1936.

Berg, I.A., Kockelkorn, D., Buckel, W., and Fuchs, G. (2007). A 3-hydroxypropionate/4-hydroxybutyrate autotrophic carbon dioxide assimilation pathway in archaea. Science 318, 1782-1786.

Bonacci, W., Teng, P.K., Afonso, B., Niederholtmeyer, H., Grob, P., Silver, P.A., and Savage, D.F. (2012). Modularity of a carbon-fixing protein organelle. Proc Natl Acad Sci USA 109, 478-483.

Cai, Z., Liu, G., Zhang, J., and Li, Y. (2014). Development of an activity-directed selection system enabled significant improvement of the carboxylation efficiency of Rubisco. Protein Cell 5, 552-562.

Calvin, M. (1949). The path of carbon in photosynthesis. J Chem Edu 26, 639.

Calvin, M., and Massini, P. (1952). The path of carbon in photosynthesis. Experientia 8, 445-457.

Chao, R., Yuan, Y.B., and Zhao, H.M. (2015). Building biological foundries for next-generation synthetic biology. Sci China Life Sci 58, 658-665.

Cheng, S., Xing, D., Call, D.F., and Logan, B.E. (2009). Direct biological conversion of electrical current into methane by electromethanogenesis. Environ Sci Technol 43, 3953-3958.

Covshoff, S., and Hibberd, J.M. (2012). Integrating C4 photosynthesis into C3 crops to increase yield potential. Curr Opin Biotech 23, 209-214.

Dexter, J., and Fu, P. (2009). Metabolic engineering of cyanobacteria for ethanol production. Energy Environ Sci 2, 857-864.

Drake, H.L. (1994). Acetogenesis, Acetogenic Bacteria, and the Acetyl-CoA "Wood/Ljungdahl" Pathway: Past and Current Perspectives. (New York: Springer) pp. 3-60.

Ducat, D.C., and Silver, P.A. (2012). Improving carbon fixation pathways. Curr Opin Chem Biol 16, 337-344.

Evans, M.C., Buchanan, B.B., and Arnon, D.I. (1966). A new ferredoxindependent carbon reduction cycle in a photosynthetic bacterium. Proc Natl Acad Sci USA 55, 928-934.

Genkov, T., Meyer, M., Griffiths, H., and Spreitzer, R.J. (2010). Functional hybrid Rubisco enzymes with plant small subunits and algal large subunits: engineered rbcS cDNA for expression in chlamydomonas. J Biol Chem 285, 19833-19841.

Gong, F., Liu, G., Zhai, X., Zhou, J., Cai, Z., and Li, Y. (2015). Quantitative analysis of an engineered $\mathrm{CO}_{2}$-fixing Escherichia coli reveals great potential of heterotrophic $\mathrm{CO}_{2}$ fixation. Biotechnol Biofuels 8,86 .

Guadalupe-Medina, V., Wisselink, H.W., Luttik, M.A., de Hulster, E., Daran, J.M., Pronk, J.T., and van Maris, A.J. (2013). Carbon dioxide fixation by Calvin-Cycle enzymes improves ethanol yield in yeast. Biotechnol Biofuels 6, 125.

Herter, S., Farfsing, J., Gad'On, N., Rieder, C., Eisenreich, W., Bacher, A., and Fuchs, G. (2001). Autotrophic $\mathrm{CO}_{2}$ fixation by chloroflexus aurantiacus: study of glyoxylate formation and assimilation via the 3-hydroxypropionate cycle. J Bacteriol 183, 4305-4316.

Huber, H., Gallenberger, M., Jahn, U., Eylert, E., Berg, I.A., Kockelkorn, D., Eisenreich, W., and Fuchs, G. (2008). A dicarboxylate/4-hydroxybutyrate autotrophic carbon assimilation cycle in the hyperthermophilic Archaeum Ignicoccus hospitalis. Proc Natl Acad Sci USA 105, 7851-7856.

Ishikawa, C., Hatanaka, T., Misoo, S., Miyake, C., and Fukayama, H. (2011). Functional incorporation of sorghum small subunit increases the catalytic turnover rate of Rubisco in transgenic rice. Plant Physiol 156, 1603-1611. 
Jahn, U., Huber, H., Eisenreich, W., Hugler, M., and Fuchs, G. (2007). Insights into the autotrophic $\mathrm{CO}_{2}$ fixation pathway of the archaeon ignicoccus hospitalis: comprehensive analysis of the central carbon metabolism. J Bacteriol 189, 4108-4119.

Kebeish, R., Niessen, M., Thiruveedhi, K., Bari, R., Hirsch, H.J., Rosenkranz, R., Stäbler, N., Schönfeld, B., Kreuzaler, F., and Peterhänsel, C. (2007). Chloroplastic photorespiratory bypass increases photosynthesis and biomass production in Arabidopsis thaliana. Nat Biotechnol 25, 593-599.

Keller, M.W., Schut, G.J., Lipscomb, G.L., Menon, A.L., Iwuchukwu, I.J., Leuko, T.T., Thorgersen, M.P., Nixon, W.J., Hawkins, A.S., Kelly, R.M., and Adams, M.W.W. (2013). Exploiting microbial hyperthermophilicity to produce an industrial chemical, using hydrogen and carbon dioxide. Proc Natl Acad Sci USA 110, 5840-5845.

Khunjar, W.O., Sahin, A., West, A.C., Chandran, K., Banta, S., and Han, A. (2012). Biomass production from electricity using ammonia as an electron carrier in a reverse microbial fuel cell. PLoS ONE 7, e44846.

Kim, B.W., Chang, H.N., Kim, I.K., and Lee, K.S. (1992). Growth kinetics of the photosynthetic bacterium Chlorobium thiosulfatophilum in a fedbatch reactor. Biotechnol Bioeng 40, 583-592.

Kumar, A., Li, C., and Portis, A.R. (2009). Arabidopsis thaliana expressing a thermostable chimeric Rubisco activase exhibits enhanced growth and higher rates of photosynthesis at moderately high temperatures. Photosynth Res 100, 143-153.

Lan, E.I., and Liao, J.C. (2011). Metabolic engineering of cyanobacteria for 1-butanol production from carbon dioxide. Metab Eng 13, 353-363.

Lan, E.I., and Liao, J.C. (2012). ATP drives direct photosynthetic production of 1-butanol in cyanobacteria. Proc Natl Acad Sci USA 109, 6018-6023.

Li, H., Opgenorth, P.H., Wernick, D.G., Rogers, S., Wu, T.Y., Higashide, W., Malati, P., Huo, Y.X., Cho, K.M., and Liao, J.C. (2012). Integrated electromicrobial conversion of $\mathrm{CO}_{2}$ to higher alcohols. Science 335, 1596-1596.

Lin, M.T., Occhialini, A., Andralojc, P.J., Parry, M.A.J., and Hanson, M.R. (2014). A faster Rubisco with potential to increase photosynthesis in crops. Nature 513, 547-550.

Martinez, A., Bradley, A.S., Waldbauer, J.R., Summons, R.E., and DeLong, E.F. (2007). Proteorhodopsin photosystem gene expression enables photophosphorylation in a heterologous host. Proc Natl Acad Sci USA 104, 5590-5595.

Mattozzi, M., Ziesack, M., Voges, M.J., Silver, P.A., and Way, J.C. (2013). Expression of the sub-pathways of the Chloroflexus aurantiacus 3-hydroxypropionate carbon fixation bicycle in E. coli: toward horizontal transfer of autotrophic growth. Metab Eng 16, 130-139.

Nevin, K.P., Woodard, T.L., Franks, A.E., Summers, Z.M., and Lovley, D.R.
(2010). Microbial electrosynthesis: feeding microbes electricity to convert carbon dioxide and water to multicarbon extracellular organic compounds. MBio 1, e00103-10-e00103-10.

Oleary, M.H. (1982). Phosphoenolpyruvate carboxylase - an enzymologists view. Annu Rev Plant Phys 33, 297-315.

Olivier, J.G.J., Janssens-Maenhout, G., Muntean, M., and Peters J.A.H.W. Trends in global $\mathrm{CO}_{2}$ emissions-2013 report. (2013). PBL Netherlands Environmental Assessment Agency.

Price, G.D., Badger, M.R., and von Caemmerer, S. (2011). The prospect of using cyanobacterial bicarbonate transporters to improve leaf photosynthesis in C3 crop plants. Plant Physiol 155, 20-26.

Price, G.D., Pengelly, J.J.L., Forster, B., Du, J., Whitney, S.M., von Caemmerer, S., Badger, M.R., Howitt, S.M., and Evans, J.R. (2013). The cyanobacterial CCM as a source of genes for improving photosynthetic $\mathrm{CO}_{2}$ fixation in crop species. J Exp Bot 64, 753-768.

Ragsdale, S.W. (1997). The eastern and western branches of the Wood/Ljungdahl pathway: how the east and west were won. Biofactors $6,3-11$.

Rosenthal, D.M., Locke, A.M., Khozaei, M., Raines, C.A., Long, S.P., and Ort, D.R. (2011). Over-expressing the C3 photosynthesis cycle enzyme sedoheptulose-1-7 bisphosphatase improves photosynthetic carbon gain and yield under fully open air $\mathrm{CO}_{2}$ fumigation (FACE). BMC Plant Biol $11,123$.

Stitt, M., Lunn, J., and Usadel, B. (2010). Arabidopsis and primary photosynthetic metabolism-more than the icing on the cake. Plant J 61, 1067-1091.

Strauss, G., and Fuchs, G. (1993). Enzymes of a novel autotrophic $\mathrm{CO}_{2}$ fixation pathway in the phototrophic bacterium Chloroflexus aurantiacus, the 3-hydroxypropionate cycle. Eur J Biochem 215, 633-643.

Whitney, S.M., Houtz, R.L., and Alonso, H. (2011). Advancing our understanding and capacity to engineer nature's $\mathrm{CO}_{2}$-sequestering enzyme, $\mathrm{Ru}$ bisco. Plant Physiol 155, 27-35.

Yu, J. (2012). Artificial photosynthetic system for high efficiency capture and conversion of solar energy and carbon dioxide. Power Enerery Sys, Lect Notes Inf Technol 13, 64-69.

Zhou, J., Zhang, H., Meng, H., Zhang, Y., and Li, Y. Production of optically pure D-lactate from $\mathrm{CO}_{2}$ by blocking the PHB and acetate pathways and expressing D-lactate dehydrogenase in cyanobacterium Synechocystis $\mathrm{sp}$. PCC 6803. Proc Biochem 2014, 49: 2071-2077.

Zhou, J., Zhang, H., Zhang, Y., Li, Y., and Ma, Y. (2012). Designing and creating a modularized synthetic pathway in cyanobacterium Synechocystis enables production of acetone from carbon dioxide. Metab Eng 14, 394-400.

Zhuang, Z.Y., and Li, S.Y. (2013). Rubisco-based engineered Escherichia coli for in situ carbon dioxide recycling. Bioresour Tech 150, 79-88.

Open Access This article is distributed under the terms of the Creative Commons Attribution License which permits any use, distribution, and reproduction in any medium, provided the original author(s) and source are credited. 